\title{
Engels' Intentions in Dialectics of Nature
}

\begin{abstract}
KAAN KANGAL*
ABSTRACT: Reading different or controversial intentions into Marx and Engels' works has been somewhat a common but rather unquestioned practice in the history of Marxist scholarship. Engels' Dialectics of Nature, a torso for some and a great book for others, is a case in point. A bold line seems to shape the entire Engels debate and separate two opposite views in this regard: Engels the contaminator of Marx's materialism vs. Engels the self-started genius of dialectical materialism. What Engels, unlike Marx, has not enjoyed so far is a critical reflection upon the relationship between different layers of this text: authorial, textual, editorial and interpretational. Informed by a historical hermeneutic, inquiry into the elements that structure the debate on "Dialectics of Nature," and into the different political and philosophical functions attached to it, makes it possible to relocate the meaning of "dialectics" in a more precise context. Engels' dialectics is less complete than we usually think it is, but he achieved more than most scholars would like to admit.
\end{abstract}

KEYWORDS: Engels, dialectics of nature, MEGA, philosophy, natural science

I

T IS NOT VERY UNUSUAL in the history of Marxism that scholarly debates turn into battlefields. The reception history of Engels' Dialectics of Nature in the 20th century seems to be such a case. In fact, I am not aware of any other work that has been subject to as much conflict and chaos in Marxist scholarship. If there were a count of attacks, it is very likely that Engels would win. Engels critique, in

* I would like to thank Terrell Carver, Sven-Eric Liedman, Vesa Oittinen, Sean Sayers, Helena Sheehan, Thomas Weston and anonymous referees for their comments on previous drafts of this paper. 
particular critique of Dialectics of Nature, has a history for almost a century, and I doubt that it will end soon.

Engels has been charged by a series of scholars with metaphysics, dogmatism, eclecticism, positivism, etc. We are told that dialectics of nature is Engels' own invention, and that it should be distinguished from Marx's social scientific enterprise. This sharp contrast between Marx and Engels, and accusations against Engels' alleged flaws, were then opposed by another group of scholars. The latter hold that whatever stands and falls with materialist dialectics is not an invention of Engels but a product of Marx and Engels' collaboration. Accordingly, Marx and Engels do not fall apart but rather complement each other with regards to dialectics of nature.

Engels' critics believed that we should simply drop this idea and move on. Engels' supporters, by contrast, typically opposed this tendency. The old debate thus clustered around an extremely narrow question of whether Engels earned his place in Marxism or not. ${ }^{1}$ Subsequently, Marx scholarship turned into a quotology wherein the circumstantial textual evidence wins the argument.

From today's vantage point, one might rightfully expect that such concerns as Marx's alleged (dis)approval of Engels' application of dialectics should have come down to more fundamental questions: How to understand Engels' dialectics in its own right, in the text as he has written it? What were his intentions and goals? What did he achieve and where did he fail?

These questions hardly need justification, for if application of dialectics to nature is the central issue here, the definition of dialectics and its relation to opposition and contradiction are binding. The difficulty is not that Engels did not define or use these key words in a systematic manner, but that he was at times inconclusive or ambiguous. Throughout the years, his intentions were changing as he was setting different problems for himself and speaking to different audiences. These intentions deserve a reconsideration without anyone else giving voice to him, or speaking on his behalf. Thus, what Marx would have said of Engels' dialectics is less decisive than one might usually think in this regard.

1 My coinage of the term "the Engels debate" might be misleading, for Engels' texts have been discussed in a variety of ways in various (Soviet, German or Chinese) traditions. Here I simply refer to the criticism of Engels' attempted application of dialectics to nature and direct responses to it. In what follows, I will be able to summarize only a small number of the diverse positions involved in the Engels controversy. 
That the past scholarship tended to ignore Engels' incomplete intentions or failed achievements is evident from the chronicle of the Engels debate. For it was never only about Engels' science; his intellectual prestige and political authority were at stake. Challenging or defending him was, and still is, ideologically motivated, though that motivation sometimes led scientific argument to accusation and insult. Dismissive attacks rather than reasoned arguments shaped much of the polemical framework in this literature. Its ultimate result was that different, indeed conflicting and controversial, meanings were attached to Engels' text that are not necessarily there. Present interpretations were often projected into a past text, though this put at risk a clear distinction between author's intentions, his text and its subsequent readings. A by-product of this fallacy to which it contributed in turn is the editorial aspect of the text. In its 60 years of publication history (1925-1985), Engels' text has been presented and read differently. With each different title selection and manuscript arrangement in subsequent editions of the book, the audience met, and was supposed to meet, a different Engels. Invariably, however, a completeness and maturity of his dialectics was always imposed.

In this inquiry, I will first revisit the old debate and the editorial history that accompanied it. I will then undertake a philological analysis of Engels' philosophical terminology in Dialectics of Nature and Anti-Dühring. This will show that 1) Engels' treatment of, and emphasis on, dialectics is heterogeneously distributed in various stages of his project; 2) AntiDühring develops a more systematic case for dialectics of nature than the Dialectics of Nature itself; 3) Engels shifts his focus from philosophical dialectics to natural-scientific theories of motion in the post-Anti-Dühring period; and 4) his historical references to past dialectical philosophies (Aristotle, Kant, Hegel) are too sketchy and inconclusive. Regarding the last point, he remains silent when it comes to alternative configurations of dialectics, contradiction and opposition. He takes it for granted that they are necessarily connected. His references, by contrast, lead to other conclusions. For example, contradiction can be logical without being dialectical (Aristotle); opposites can be dialectical without being real (Kant); opposites are dialectical, but contradictions are speculative (Hegel). Needless to say, alternative organizations of these concepts can lead to different understandings of a dialectics of nature.

Engels was probably not oblivious to such problems and he expressed, implicitly or explicitly, a need for a fuller historical and 
systematic approach. Nevertheless, such intentions remained largely incomplete, an aspect which most participants in the Engels debate hardly take seriously. The present article suggests a re-reading of Engels that takes both Engels' accomplishments and unresolved issues into account.

\section{The Engels Debate}

Lukács is probably the first scholar who viewed the application of dialectics to nature as a problem. He argues that Engels was "following Hegel's mistaken lead" by extending "the [dialectical] method to apply also to nature" $(1971,24){ }^{2}$ Dialectics, however, is "limited . . to the realms of history and society." Unsurprisingly, the "methodology of natural sciences ... rejects the idea of contradiction and antagonism in its subject matter" (Lukács, 1971, 10; 1977, 175). Social reality and social sciences, by contrast, necessarily involve contradiction and antagonism (ibid., 181-2). "Theory," unlike natural science, reveals "real tendencies of processes of social development" and opens up the way to "overcoming" and "removing" these contradictions ( ibid.). ${ }^{3}$

Deborin $(1924,69)$ ridicules Lukács' attempt to lecture Engels about dialectics and charges his defense of Marxism against Engels with "dualism." He is an "idealist as far as his account of nature is concerned, but a dialectical materialist with regards to social historical reality" (ibid., 51). "From the point of view of dialectical materialism, nature itself is dialectical. And to this extent, our knowledge of nature is dialectical." Idealists such as Lukács "are apparently not capable of grasping the objective character of dialectical processes in nature and history" (ibid., 58-9).

Following the publication of the first edition of Dialectics of Nature in $1925,{ }^{4}$ I. I. Stepanov $(1925,60)$, a prominent Soviet Mechanist,

2 Unless otherwise noted, all translations are my own.

3 Two years later, Lukács $(2000,93 ; 1999,121)$ will be defending himself against his opponents by claiming that it is "the development of science that drums the dialectic into the natural scientists." "Self-evidently the dialectic could not possibly be effective as an objective principle of development of society, if it were not already effective as a principle of development of nature before society, if it did not already objectively exist" (Lukács, 2000, 102; 1999, 128). Also note here the English mistranslation of the chapter title "Dialektik in der Natur" (Dialectics in Nature) as "Dialectics of Nature" (2000, 94; 1999, 114).

4 John Bellamy Foster $(2000,229)$ wrongly dates the first edition back to 1927. Levine (2006, 3 ) is mistaken in asserting that it was "printed in the Soviet Union in full in 1927." The complete version was published by MEGA² in 1985 in East Germany. 
divides Engels' view on nature into Hegelian nature-philosophical and scientific-materialist phases, evolving from the former to the latter. That "Engels the dialectician" becomes later "Engels the mechanist," Deborin $(1925,10,17)$ protests, is Stepanov's imagination. Engels, early and late, is simply at pains to develop "a dialectical understanding of natural processes" or "dialectics of natural sciences."

Commenting on the 1939-1941 edition, Sartre goes on to say that Engels" dialectics of nature is an "absolute principle" or "a priori and without justification," that is, it is "not open to verification at all" (Sartre, 2004, 27-8). Accordingly, "dialectic moves in the opposite direction from science" (Sartre, 1947, 165). ${ }^{5}$ Later commentators fashioned a similar criticism. The "attempt to apply the dialectic to nature must be ruled out as incompatible with a naturalistic starting point. Marx himself never speaks of a Natur-Dialektik" (Hook, 1962, 75). Marx's dialectics "expresses the logic of historical consciousness and class action." Nature is "relevant to dialectic only when there is an implied reference to the way in which it conditions social and historical activity" (ibid., 76). Engels' dialectics is an "eclectic composite of Marx's naturalism, Hegel's logic and contemporary positivism" (Lichtheim, 1972, 212). "There can be no question of a dialectic of external nature" because material reality is "always socially mediated" (Lewis, 1972, 65). All this mess goes back to "August 1859 [when] Friedrich Engels invented dialectics, the progenitor of unresolvable ambiguities within the Marxist tradition" (Carver, 1983, 117). ${ }^{6}$

The opposite camp can be called Leninist in the sense that Engels' dialectics is seen to be "in full conformity" with Marx's materialist philosophy (Lenin, 1974, 51). Dialectics of nature is "no invention of Engels." On the contrary, "it was worked out in collaboration with Marx and had his full agreement" (Hoffman, 1975, 56). Those who separate Marx

5 For further commentary on this debate see Merleau-Ponty, 1947, 173; Gretskii, 1964; Schmidt, 1965; Novack, 1996, 231-55; and Remley, 2012.

6 These views are repeated over and over again by Lichtheim, 1964, 246; Jordan, 1967; Colletti, 1973, 46; Avineri, 1975, 70; Levine, 1975, 145; Gunn, 1977, 46; Rayner, 1977, 154; Attenborough, 1978, 31; Kołakowski, 1978, 379; Carver, 1980, 360; Schmidt, 1993, 55-6; Althusser, 2005, 121-122; Paolucci, 2007, 245; Carchedi, 2011, 37-8; Carchedi, 2012, 547. For more detail also see Rigby, 2007, 103-108, and Sheehan, 1993, 53-60. The British debate was closely followed by Chinese scholars (see Dai, 1978), but a critical assessment of the Engels controversy here or elsewhere is usually not visible. In more recent Chinese literature on dialectics of nature, a non-problematic Marx-Engels relation is rather monolithically taken for granted (see Hu, 2006; Wu, 2014; Xiao, et al., 2016). Hu Daping's monography of Engels (2011, 492-506) and Zhou Lindong's thorough discussion (Zhou, 2001) are notable exceptions. 
from Engels falsify the fact that Marx actually endorsed Engels' natural dialectics. He "took a strong interest in science and regarded a dialectics of nature as essential to his theory of a unified science" (Stanley and Zimmermann, 1984, 226). No true scholarship but a hidden anticommunism is behind those who come up with charges against Engels and separate him from Marx (Oiserman, 1978, 44-45). ${ }^{7}$

The alleged contamination of Marx's work by Engels is usually resisted by appeals to textual authority such as Marx's contribution to Anti-Dühring or the Marx-Engels correspondence. While Leninists might have been well aware of the need for a closer consideration of alternative positions, they were rather alerted by, and directly responding to, a scapegoat mechanism operated by their counterparts. What both sides have in common is that they both argue that there is only one single right interpretation of Engels: their own. They just disagree on the question of whether a satisfying answer to the problem of Engels' dialectics can be given by an authentic Marx freed from Engels. There is either Marx and Engels, or Marx against Engels. Engels' dialectics either belongs to the canons of Marxism, or not.

My problem with these sorts of readings is that, when claiming authority for the proper reading of Engels, both views rule out the possibility of another perspective that insists upon understanding Engels in his own right in the text as he has written it. Certainly, any reading occurs from a present vantage point, and it is done for present purposes, political or otherwise. But this cannot mean that we can ascribe to Engels' text any value or meaning we wish, such as systematicity or completeness. B. M. Kedrov (1971), for instance, does this by calling it "Engels' Great Book." The problem is not that it was not great; rather, that it was not a book. It rather became a book, posthumously, through subsequent editions of Dialectics of Nature. In the next section, I will spend some time on the history of this "book" and the meanings that are attached to it.

\section{Creation of a Book: "Dialectics of Nature"}

The first piece of text ("The Part Played by Labor in the Transition from Ape to Man") from what came to be known later as Dialectics of

7 For the Leninist line, also see Timpanaro, 1975, 74; Gray, 1977; Greaves, 1977; Hoffman, 1977; Rayner, 1977; Torbe, 1977; Korch, 1978; Cohen, 1980; Moran, 1980; Levins and Lewontin, 1985, 279; Sève, 1992; Stanley, 2002; Holz, 2005; Weston, 2012; Altvater, 2015, 36; Kangal, 2017. 
Nature was published by Eduard Bernstein, one of the German Social Democratic leaders (SPD) and an executor of the literary estate of Marx and Engels, in 1895-96. This was followed by "Natural Science in the Spirit World" in 1898. A majority of the Marx-Engels correspondence relevant to the later Engels debate was edited and published by Bernstein in 1913, as well. The SPD also entrusted German physicist Leo Arons with the task of assessing whether Engels' manuscripts on dialectics of nature were worth publishing. Arons came to a negative assessment, claiming Engels' works are outdated (Griese, et al., 1985, 594-5; Griese and Pawelzig, 1995) ${ }^{8}$ Several years later, Bernstein asked Albert Einstein's opinion. Einstein $(2015,414)$ believed that the manuscripts have no merits from the perspective of contemporary physics, but they give interesting insights into Engels' intellectual biography. In the 1920s, David Riazanov, Director of the Marx-Engels Institute in Moscow and chief editor of the historical-critical edition of the Marx-Engels Collected Works (MEGA), borrowed the manuscripts from Bernstein and copied them all in 1923.

Dialectics of Nature was published first in 1925 in the German original and Russian translation, under the titles "Naturdialektik" and "Dialektika Prirody" (Dialectics of Nature) ${ }^{9}$ It included most of the manuscripts, except some formulas, calculations and the "1878 Plan." In a 1927 edition, the title was changed to "Dialektik und Natur" (Dialectics and Nature). This edition, unlike the previous one, included "Preparatory Works for Anti-Dühring," but omitted the fragment "Transition from Ape to Man." In both editions, manuscripts were published according to chronological order. This was then reproduced in the 1929 and 1931 Russian editions. A new German edition was prepared in 1935, with corrected decipherments of the manuscripts and additional remarks on the texts. This time it included the "1878 Plan" and "Motion of Planetary Bodies" in it, but omitted "Slavery, Fourier, Concerning the Value of an Object." A newer Russian edition (1939-1941) switched the title back to Dialektika Prirody (Dialectics of Nature). This put both "1878 Plan" and "Dialectics" in

8 Arons' negative decision, Bernstein speculates, might originate from the former's sympathy for empiricism and distaste for dialectics (Griese, et al., 1985, 596).

9 Note here that "Naturdialektik" and "Dialektik der Natur" are different formulations, even if there is no obvious difference in terms of their meaning. Russian or English do not follow this difference ("Dialectics of Nature" or "Dialektika Prirody"). At that time, they were not published in MEGA but first in Russian and German in the Marx-Engels Archive, then as a special edition (Sonderausgabe), as in 1935. 
the very beginning, followed by "Articles and Chapters," indicating that Engels' natural scientific studies illustrate a certain number of dialectical laws or axioms. This edition also served as the textual basis for all the subsequent editions in Russian, German and English, etc. (Griese, et al., 1985, 597-8). ${ }^{10}$

The latest version appeared in MEGA in 1985, with both chronological and systematic order. Unlike previous versions, this edition consisted of everything transmitted from Engels via Bernstein to Riazanov, without any omissions. Nevertheless, it is curious that one volume presents two different versions of the same text. The decision for a bi-versioned edition goes back to a discussion between Russian and German editors in the 1980s. A systematic order of the manuscripts was against the editorial principles of the historical-critical edition. But the former version, unlike the latter one, presents "the logical structure of the work" much better (Griese and Pawelzig, 1995, 56). The debate ended with the compromise of publishing both versions.

All the editors listed above saw their task as establishing a version of the text which is as authentic as possible in the sense that their arrangement of manuscripts and the specific choices they make of a certain version reflect the author's final and binding intention. Editors' judgments naturally depend on their image of the author. And the way they evaluate author's work determines how they decide to present it. In Engels' case, however, their professional role was not limited to being a middleman between the author and his readers. They were supposed to take into account the political-philosophical concerns of Marxism, Engels' role in it and the proper presentation form of Engels' text that does address such issues. In other words, they were partially in charge of how Dialectics of Nature should function in the context of Marxism.

The earliest example of this is of course the first edition. Lukács' challenge to Engels and Marx's alleged disagreement with him was reflected in the titles given to the book. Interestingly, Luppol (1930, 171) claimed in 1925 that the publication of the book would put an end to the debate. Naturally, this never happened. The chronological

10 There are also Kedrov's less known Russian-German editions (1973-79). Kedrov called them "Friedrich Engels on Dialectics of Natural Science." The title and manuscript arrangement suggest that Engels' enterprise is not really about a dialectical ontology of nature but an epistemology of natural sciences. This view gave rise much later to another debate in Germany on "dialectics of nature" vs. "dialectics of natural science" (see Holz, 2005, 552-556). 
order, to name an example, was used by Stepanov for an unexpected division between early and late Engels. The systematical order of the later editions that opens with Engels' two plans and nature-scientific material subordinated to them, by contrast, not only aimed to avoid similar interpretations but also to make the book more accessible to a wider public. What the editors certainly did not predict was that Engels' dialectical laws would be subject to another controversy, as in the French debate.

As far as the editors' role in these quarrels is concerned, there is at least one unmistakable tension here. It is the gap between the editor as advocate or executor of the author's will and the editor who reads, comments on and presents the text in the interest of readers, so that they read Engels' text as it is decreed to mean. Now this has to do not only with adding authority and status, or assigning a function, to Engels' text. When polishing and resituating the book in a newer political intellectual setting, the editors also reconstruct an idea which they believe is behind that work.

This idea, which the editors, following Engels, called "Dialectics and/of Nature/Natural Science," assumes the accuracy and clarity of Engels' terminology. I doubt this is entirely true. Engels certainly gives clues about his general tasks and problems in various places in the text, though they are usually too sketchy. A historical-critical account of the term "dialectics," in relation to previous understandings, is a case in point. Two other equally important terms that belong to the same body of thinking - opposition and contradiction - suffer from the same problem. In what follows, I will examine Engels' understanding of, and references to, dialectics and anything related to it in the text, and speculate about possible scenarios of a fuller account in this regard. This will clarify the difference between what he says in the text and how he is interpreted in the later readings.

\section{Engels' Dialectics in the Text}

When Engels might have first launched his project and when he ended it is a mystery. For some, Dialectics of Nature goes back to the 1840s or 50s (Kedrov, 1979, 443). ${ }^{11}$ Others believe it starts in 1873 with

11 Kedrov ambiguously speaks of a single "Manchester time." This is misleading, for Engels had at least two (1840s and 1850s) Manchester periods. 
the earliest manuscript of the book (Gemkow, 1988, 447). According to a third approach (Liedman, 1986, 99), it starts in July 1858 when Engels $(1978,337-8)$ asks Marx to send him a copy of Hegel's Philosophy of Nature, emphasizing its promising potential for chemistry, biology and physiology. More often than not, Engels' engagement in Anti-Dühring between 1876 and 1878 is seen as a break, after which he returns to his initial plan, which is interrupted again by Marx's death and the edition of volumes II and III of Capital. Regarding the end of the project, we are offered two alternatives: it is either Marx's death in 1883 or Engels' death in 1895. Ordinarily, it is hard to determine an exact time span for Engels' work in this context, for it can be argued that even the young Engels' studies of natural sciences and dialectics gave rise to Dialectics of Nature, a terrain which he never leaves.

Nevertheless, 197 manuscript fragments, which Engels put in four folders - naming them "Dialectics and Natural Science," "Natural Research and Dialectics," "Dialectics of Nature," and "Mathematics and Natural Science" - are the textual material transmitted to Riazanov (Griese, et al., 1985, 570). The earliest text in those folders is Engels' critical study of Büchner's mechanical materialism from February 1873, and the latest one is an unpublished fragment (beginning of 1886) from his late article on Feuerbach (ibid., 599 and 607). As in the latter case, it is hard to call other works, such as Anti-Dühring, "breaks" from this project. Besides the fact that the content of Feuerbach, Anti-Dühring and Socialism are closely connected to Dialectics of Nature, Engels wrote more than 60 manuscripts of Dialectics of Nature in the period 1876-78. Also note that the "Old Preface on Dühring. On Dialectics" found a place in the folder "Natural Research and Dialectics" (ibid., 606). If Anti-Dühring was really a "break," one ought to use the term in a very loose sense.

As for dialectics, Anti-Dühring is especially interesting because nowhere else does Engels address the questions of dialectics in such a systematic manner. It can even be argued that Anti-Dühring builds a much stronger case for dialectics of nature than Dialectics of Nature itself. Although past scholarship often takes them as if they are one and the same text, Engels seems to be speaking to different audiences in them. While the chapters in Anti-Dühring on philosophy, nature and dialectics attempt to justify the existence of real contradictions in nature and society, the gist of Dialectics of Nature, especially its late stages, is about universal structures and the history of motion in 
nature. If the postulated reader of Anti-Dühring is Dühring himself and his supporters, Dialectics of Nature speaks primarily to natural scientists and to a wider public puzzled by the challenges of contemporary natural sciences to old-fashioned dialectical philosophy. In other words, Dialectics of Nature is more about nature and less about dialectics, and I think this is a problem. If Engels thought that his account of dialectics in Anti-Dühring is satisfying enough so that he can invest more energy into the analysis of structures and the history of motion in nature, then I would ask how this conviction is justified and to what extent. A closer examination of Engels' dialectical terminology in both texts will be illuminating in this regard.

\section{Dialectics in Anti-Dühring}

Eugen von Dühring, a professor at Berlin University and an influential intellectual in SPD circles, caught Engels' attention first with his critical review of Marx's Capital which Engels $(1974,8)$ reports to Marx in January 1868. In his reply, Marx (1974a, 9) writes that Dühring misunderstood many things, including his dialectics and its distinction from that of Hegel. ${ }^{12}$ Marx $(1974 b, 18)$ calls him ironically "a great philosopher," for "he wrote a 'Natural Dialectics' against Hegel's 'unnatural' one." Dühring's massive publications in the following years and his persistent criticism of Hegelian dialectics were perceived in socialist circles as the rise of a new rival of Marx. In 1875, Wilhelm Liebknecht encourages Engels to write a response. It is evident from a May 1876 letter to Marx that Engels $(1966,12)$ was tempted by Dühring's renewed attacks. A counter-attack was inevitable.

According to Dühring $(1873,452)$, Marx's Capital is written in a fully Hegelian spirit. Marx not only adopts Hegel's dialectical categories in the exact same order and applies them to the critique of political economy but also repeats the same mistake of Hegelian dialectics. This flaw, so the argument goes, is the so-called principle of contradiction. Contradictions are actually "absurdities" of logic (ibid., 445). Hegel's idealism, however, confuses concepts with reality and projects the notion of contradiction into the real world (Dühring, 1875, 30). There is no such thing as a "real contradiction" (realer Widerspruch) (ibid., 32). Contrary to this "arabesque" "unlogic" (Dühring, 1873, 
446, 453), Dühring $(1865,113)$ offers a "Natural Dialectics" (Natürliche Dialektik) that adopts another structural core unit: unity of opposites. Interrelation and interpenetration of mechanical forces in nature are "real opposites." Real opposites are "antagonisms" (Antagonismus) or "conflicts" (Widerstreit) (Dühring, 1875, 31).

In his response, Engels argues that Dühring explains the problem away by calling real contradictions "antagonisms." Engels not only elaborates this claim but also distinguishes three types of contradictions which might be called 1) contradictions in nature, 2) contradiction as theoretical inconsistency, and 3) contradictions inherent to any scientific theory. The basic tenet of the first type is a list of elaborated examples of real opposites in nature such as necessity and coincidence, interaction of opposite physical forces or cause and effect. He famously claims that "motion itself is contradiction" (Engels, 1988, 318). The second type is called "absurd contradiction" (ibid., 257). This is close to Dühring's usage of the term, but Engels directs it against Dühring's flaws. The third type is located between mankind's attempt "to gain an exhaustive knowledge of the world system in all its interrelations" and its inevitable failure to completely fulfill this task (ibid., 245). We have to do with a contradiction between humanity's potentially unlimited capacity for knowledge and its biological, physical or cognitive limitations in single individuals (ibid., 288). This contradiction finds its solution "in the endless progressive development of humanity" (ibid., $245)$ and in "an endless succession of generations, in infinite progress" (ibid., 319) of knowledge "from known to unknown" (ibid., 330).

Following this threefold division of contradiction, Engels offers three compatible definitions of dialectics: dialectics as 1) contradictory structures in nature, 2) a certain method of thinking, and 3) a holistic theory of totality. As for the first definition, he writes that "the kernel of dialectical conception of nature" is the recognition of "opposites and differences" (Gegensätze und Unterschiede) in nature (ibid., 497). Any process is by its nature "antagonistic" (antagonistisch), that is, it contains a "contradiction" (Widerspruch) or "transformation of one extreme into its opposite" (Umschlagen eines Extrems in sein Gegenteil) (ibid., 335). This is the real foundation of what he calls a "method of thinking" (Denkmethode) (ibid., 233) that operates "within polar opposites" (in polaren Gegensätzen) (ibid., 292). However, it "does not build dialectical laws into nature but discovers them in it" (ibid., 495). This leads to the third definition: "dialectics is . . the science of 
general laws of motion and development of nature, human society and thought" (ibid., 336). In other words, unity of contradictory opposites is an elementary and universal structure present in nature, society and thought. In each of these spheres of reality, it takes a different form and it is treated differently from different aspects of dialectics.

\section{Dialectics in Dialectics of Nature}

From the angle of Anti-Dühring (1876-78), it is clear that much of Engels' dialectical fire is transferred from the $1873-76$ period. The term "contradiction" reaches its peak in Anti-Dühring, to say the least. As for the contrast between different periods, all aforementioned types of contradiction are used in the pre-Anti-Dühring period, though less frequently. Real contradictions are openly called contradictions here, but after Anti-Dühring (1878-86) the term is almost always mentioned in the sense of theoretical inconsistency. The only exception is the "1878 Plan." This he revises in 1880 and then drops the term.

In a way, such a slippage in the very late stage of his work leaves the impression that Anti-Dühring absorbed much of what Engels could have said about dialectics and contradiction. Once it is clear in the eye of the reader, he may have thought, that motion is contradiction and everything is in motion, then the puzzle of dialectics is solved. Also note here that the keyword of the post-Anti-Dühring period, especially in the "1880 Plan," is not dialectics or contradiction but motion (in nature, society and thought).

Let me start with real contradictions. They are explicitly mentioned only three times in Dialectics of Nature. The first occasion (November 1875 ) is when he speaks of Newton's physics and its analysis of planetary motion. The relation between attraction of the Sun and the so-called tangential-force "run into a contradiction" (Engels, 1985, 45). It appears for a second time (October-November 1877) in his characterization of the relation between necessity and coincidence (ibid., 137). This is combined with contradiction in the sense of theoretical inconsistency when he charges metaphysics with ignoring the existence of real contradictions. Finally, the term shows up in his "1878 Plan" (August-September 1878) as one of the laws of dialectics: "development through contradiction or negation of negation" (ibid., 173).

In the sense of theoretical inconsistency, the term sometimes (November 1875-May 1876) refers to a "contradiction" within the 
anti-evolutionary world view, according to which the earth does change but the living organisms on it do not (ibid., 76). Elsewhere (OctoberNovember 1877), Engels argues that Hegel's view on coincidence and necessity is viewed by natural sciences as a "paradoxical language game" (paradoxe Sprachspielerei) or "self-contradictory nonsense" ( sich selbst widersprechender Unsinn) (ibid., 139). Other examples, such as contradictions between claims and natural laws (February-July 1880) or contradictions as errors (January-August 1882), are also present (ibid., 190, 259).

There is also a gradually decreasing emphasis on the existence of real opposites from the early to late stages of the work. While they are mentioned very often in the pre-Anti-Dühring period, this is less so after Anti-Dühring. One persistent concern (February 1873) is to rescue opposite pairs such as cause and effect or identity and difference from their metaphysical treatment (ibid., 5). Another (Summer 1874) is to prove that, for example, a structure of polarization is present in both physical nature and human thinking (ibid., 13). Engels' examples, from mathematics and geometry to physics (November 1875, February-July 1880), are well known (ibid., 41, 42, 48, 50, 189). As in the "1878 Plan," they are ordinarily called "polar opposites" (polare Gegensätze). He also speaks of "interpenetration of opposites" (Durchdringung der Gegensätze) or "main opposites" (Hauptgegensätze) (ibid., 173, 175, 190, 225).

His approach to dialectics is much more straightforward. He constantly speaks of "dialectical transitions" between natural spheres or categories (ibid., 5, 10, 28) or "dialectical relations" between opposites (ibid., 41, 190). Then we are also offered a group of definitions of dialectics: "dialectics of natural science: subject — matter in motion. Different forms and types of matter itself likewise known only through motion" (ibid., 9). ${ }^{13}$ "Dialectics, the so-called objective, prevails on entire nature and the s.c. subjective dialectics, the dialectical thinking, is only reflection of the motion through opposites which asserts itself everywhere in nature, and which by the continual conflict of the opposites and their final passage into one another" (Engels, 1987a, 492, translation modified; 1985, 48). Alternatively, it is defined as "the science of the most general laws of all motion" (ibid., 147) or "science of universal interconnection" (ibid., 173, 175). 
Similar formulations have survived at least until the "1880 Plan," when Engels (ibid., 183) changed the first axiom of his "1878 Plan" from dialectics to "motion in general," followed by "attraction and repulsion transition of motion," etc. He increasingly avoided any direct reference to, or usage of, his former dialectical terminology, and this remained more or less so until 1886.

In September 1879, Engels makes quite clear that he does not intend to "write a handbook of dialectics but only to prove that dialectical laws are laws of development of nature, thus they apply to theoretical research of nature as well" (ibid., 176). His underlying thread, as he puts it (November 1877), is "systematization of natural sci[ences], which is now becoming more and more necessary." Such a systematization "cannot be found in any other way than in the interconnections of phenomena themselves" (ibid., 144).

Already in 1874, Engels draws attention to an important distinction between natural scientific research and its unacknowledged reliance on a certain theoretical thinking. "Natural scientists believe that they free themselves from philosophy by ignoring it or cursing at it." They cannot, however, pursue science without employing scientific categories. Independent of whatever attitude towards philosophical theory they may hold, they are, and always will be, under the domination of philosophy. The only question is "whether they want to be dominated by a bad, fashionable philosophy or by a form of theoretical thinking which rests on acquaintance with the history of thought and its achievements" (Engels, 1987a, 491, translation modified; ibid., $1985,32)$.

In 1878, he describes his own enterprise as a contribution to bridging the divide between empirical sciences and philosophical theory (ibid., 167). The task he ascribes to dialectical philosophy is to articulate a solid theoretical basis of empirical natural science and corroborate some hypotheses formulated within the natural scientific program. For more self-conscious theoretical guidance, natural sciences must turn to philosophy, or more specifically to dialectics: "it is precisely dialectics that constitutes the most important form of thinking for present-day natural science, for it alone offers the analogue for, and thereby the method of explaining, the evolutionary processes occurring in nature, inter-connections in general, and transitions from one field of investigation to another" (Engels, 1987a, 339; ibid., 1985, 167). 
To this end, Engels seems to have translated his dialectical terminology into the language of natural sciences, when he writes (December 1885-January 1886) that "the unity of all motion in nature is no longer a philosophical assertion, but a natural scientific fact" (ibid., 285 ). As he puts it elsewhere (February-July 1880), motion is "conceived as the mode of existence, the inherent attribute, of matter" and it "comprehends all changes and processes occurring in the universe, from mere change of place right up to thinking" (Engels, 1987a, 362; ibid., 1985, 187).

It goes without saying that Engels premises that motion is dialectical because it is structured by the unity of opposites (identity/ difference). One ambiguity here is that he invests more and more time in investigating different forms of motion and their interconnection in nature as well as their representations in natural scientific theories. I suspect that a closer consideration, and a more precise usage, of dialectical terminology became a secondary concern here. Although he repeatedly emphasizes that the capacity of philosophical theory has to be developed and improved and that a systematic reconsideration of previous dialectical philosophies (Ancient Greek and German Idealist) is a great need (ibid., 167), he leaves a series of questions open:

Is unity of opposites necessarily contradictory? To what extent are real contradictions dialectical and how are they distinguished from the way Hegel has interpreted dialectics? In which sense can we speak of a continuity of dialectical philosophy from Ancient Greeks to German Idealists?

In the next section, I will show that Engels was aware of a need for more scrutiny of such problems, but it is also doubtful that he intended to solve them as part and parcel of the program of Dialectics of Nature.

\section{Engels' Intentions and Open Questions}

In Anti-Dühring, as I have already mentioned, Engels (1988, 318) asserts that "motion itself is contradiction." This is followed by a more curious claim: "Even simple mechanical change of position can only come about through a body being at one and the same moment of time both in one place and in another place, being in one and the same place and also not in it" (Engels, 1987b, 111; ibid., 1988, 318). 
I am afraid that the second claim neither supports nor explains the first one. It is very unlikely that he intends to speak against common sense here, for a body, at least in the sense of classical physics, cannot be here and elsewhere at the same time. When writing these lines, he perhaps thought of his 1874 sketch on physical force where he describes transference of force from one body to another. When a body applies force to another one, the result is a "manifestation" (Äußerung) of force in the latter (Engels, 1985, 18). In this restricted sense it can be said of one entity that it is here and elsewhere at the same time, though in different forms.

Moreover, the formulation of "being in the same place and elsewhere" probably originates from Parmenides and Zeno of Elea, or at least from Hegel's interpretation of them, and the thesis "motion is contradiction" goes back to Heraclitus' panta rhei (everything flows). Interestingly, Engels never borrows Parmenides' idea again. Heraclitus' panta rhei, by contrast, is reformulated many times. Engels prefers Hegel's terminology in this regard and speaks of a "dialectical relation" between "identity and difference" (Engels, 1985, 41) or "difference within identity" ( $i b i d ., 15$; see also ibid., 5, 17, 31-2, 225). One illustration of this is as follows (Engels, 1987a, 495; ibid., 1985, 14): "The plant, the animal, every cell is at every moment of its life identical with itself and becoming distinct from itself, by absorption and excreation of substances, by respiration, by cell formation and death of cells," etc. But what could he have meant by the difference being in identity?

Common sense suggests that there is identity of things, but there is also change. Now the questions are these: 1) Why call them a contradiction? 2) Why are they dialectical? Engels might have easily answered the first question, but the second one less so: they are contradictory because opposites build a unity; and they are dialectical because Hegel calls them so. Unfortunately, both answers are unsatisfying. Dühring, for instance, calls them antagonistic and dialectical but not contradictory. If Dühring's terminology is not justified, then how can Engels' be? And how can it be helpful to turn to Hegel's authority in order to call them dialectical? Such problems demand a more elaborated approach. Given all the textual material we have today, Engels does not seem to have planned to go into detail on such matters. Nevertheless, I am curious about what his approach would have looked like if he had ever intended to solve such problems for us. 


\section{Identity and Difference}

Concerning the first question, he could have argued as follows. Consider a certain object with a bunch of properties including shape, color and weight in a certain place in a given unit of time. We would identify that object based on these properties. We usually identify objects in a very loose way by paying attention to a minimum of its properties. Identification in a rather strict sense would require a complete list of all of its properties. This can be called the strict identity of an object. Now imagine a variation of at least one of its properties such as being in a different place or time, or having a different color. Given this change, the same object is not identical (in the strict sense) with its previous state, for the list of properties that makes up its previous identity has changed. In order to be strictly identical, both objects have to have all their properties in common. Obviously, this is not the case. From this angle, it is both the same object and it is not. Hence the contradiction. Now the problem is that since everything including this object is in constant change, how can we identify anything in the first place? The Hegelian answer which Engels would embrace is that our concept of identity should encompass both a strict identity and change of that object. Accordingly, the concept of identity must allow a principle of change, which, in turn, results in the opposite of what that particular identity is. Identity as such contains both identity and non-identity. ${ }^{14}$

\section{Historical Account of Dialectics}

Contradiction and opposition as well as negation of negation apply to this formula. But are they also dialectical? Engels' answer would be affirmative, because he thinks within the framework of, and ascribes dialectics to, Hegel's philosophy. And this is where the problem gets complicated. What Engels terms "dialectics" is "speculation" in Hegel. But Engels, along with Marx, uses the term "speculation" not in the Hegelian but in the Kantian sense. This raises the following question: how does Kant treat speculation and dialectics and what

14 Sean Sayers would perhaps agree with this solution. In at least two articles (1980a; 1980b) he seems to approve Engels' Hegelian formulations. However, he does not take Engels' changing intentions into account, nor does he problematize Engels' incomplete or failed attempts to develop a more elaborated approach to dialectics. 
impact does this have on configuring the relation between opposites and contradiction?

Engels (1987a, 342; ibid., 1985, 170) recommends to natural scientists "the classical German philosophy from Kant to Hegel," but he also adds that "to study dialectics in the works of Kant would be a uselessly laborious and little-remunerative task, as there is now available, in Hegel's works, a comprehensive compendium of dialectics." Dialectics has so far been rather "fairly closely investigated by only two thinkers, Aristotle and Hegel" (1987a, 339; ibid., 1985, 167). This, of course, leads us to question Aristotle's treatment of dialectical terms.

First of all, Aristotle is much closer to Kant than Engels thinks he is. And secondly, Engels ignores Aristotle's hostility towards Zeno, Parmenides, and before them, Heraclitus. This complication is joined then by Hegel's (1986a, 320) positive reception of Heraclitus: "there is no sentence of Heraclitus which I did not take into my Logic." Hegel interprets Heraclitus' "flux" as "becoming" (Werden), and its constituents as "unity of opposites" (Einheit Entgegengesetzter). Engels takes this up from Hegel and combines it with the natural scientific concept of motion. Fair enough. But where does Aristotle fit in this picture?

In Aristotle's (1991, 1062a32-5) view, Heraclitus fails to admit that two opposite (antikeimena) claims concerning the same subject-matter cannot be simultaneously true. Aristotle is even more disturbed by Parmenides and Zeno. Whereas Heraclitus defends contradictory statements about reality, Parmenides and Zeno claim that logical descriptions of real opposites inevitably give rise to contradictions. If one thing changes, they say, the result of that change cannot be identical with what has changed. And yet, it is the case that anything in motion or change is and is not at the same time (Plato, 1972, 138b7-c4).

In Physics, Book VI, Aristotle (1988, 239b5-240b8) offers a criticism of Zeno, but he does not address any of the issues discussed in Plato's Parmenides. He only contents himself with the remark that we can speak of change, say, from pale to non-pale without violating the law of exclusion of contradiction (ibid., 240a19-23). Ambiguously, he claims the opposite in Book V. There he writes that change from a non-entity to an entity or from non-pale to pale involves "contradiction" (antiphasis) (ibid., 225a). Thus he locates contradiction within motion that goes through intermediate (metaxy) stages (ibid., 224b30).

If Engels speaks of an Aristotle-Hegel line, then he perhaps had in mind Aristotle's view in Book V, and not Book VI. This would also 
justify his ambition to exclude Kant from the historical line of dialectics, as Kant is close to Aristotle of Book VI, when Kant distinguishes different types of oppositions. Kant basically says that any logical opposition is contradictory. However, there are real oppositions and they are not contradictory, for contradiction strictly belongs to mental faculties and it has nothing to do with reality. A third type is the dialectical opposition that is neither real nor logical. This type rather originates from a cognitive operation of human reason that directs itself to certain mental objects such as the absolute and unconditional. Such mental objects are structured by opposites, but they create an illusion as if they exist in reality. Accordingly, two opposite claims can be asserted of the same object. They can both be wrong without contradicting each other. Hence non-real dialectical opposites (Kant, 2016b, B 532; Kant, 2016a, 339; Wolff, 1980, 341; Arndt, 2009, 103-4).

When Engels speaks of dialectical opposites that are real and contradictory, he then refers to Hegel, rather than to the Greeks or Kant. However, the difference between Hegel and Engels is that the former views real contradictions as externalization or manifestation of logical contradictions in nature, while the latter reverses this line of reasoning in the sense that any real structure such as physical motion finds its equivalent in, and is expressed by, what the classical logic used to term "contradiction." The other difference is the meaning of dialectics in Hegel.

In Hegel's understanding, the old or rather "usual" kind of dialectics is the case when two opposite predicates are asserted of the same subject. The "more pure dialectical" form appears when one predicate simultaneously refers to itself and to its opposite. This is a contradiction (Hegel, 1986c, 56). Opposites in isolation are "abstract." If they are differentiated from, and related to, one another, they embody "the dialectical" in their "transition." The "speculative" as a higher stage of this line of thinking results from the "unity of determinations within their opposition" (Einheit der Bestimmungen in ihrer Entgegensetzung) (Hegel, 1986b, 176). For example, conceiving of identity and difference as separate entities applies to the "abstract" account. A transition from identity to difference would express the dialectical moment. That the transition of identity to difference returns to the identity itself is what speculation is about. Reconstructing the successive stages of such a mental operation is the business of Hegel's "method" (Hegel, 1986d, 553-4). Note here that Hegel never speaks of a "dialectical 
method," for dialectics is a temporary moment, and not the final result, of reconstruction of the contradictory unity of opposites.

When Engels $(1985,239)$ speaks of "the amazing aprioristic speculations of German natural philosophy," he seems to be using the term "speculation" in a typical Kantian sense. Speculative knowledge is the opposite of natural knowledge, for the latter, unlike the former, is based on, and investigates, empirical objects (Kant, 2016a, 559). Despite the fact that Engels uses the term in the Kantian sense, he objects to a strict separation of empirical and non-empirical knowledge of natural science. This gives rise to more questions than the problems Engels has believed he has solved. Engels seems to have achieved some of his goals in his pursuit of philosophy and theoretical natural science. Nevertheless, he does not seem have planned to offer a more direct and systematic approach that takes the aforementioned ambiguities into account. This points not only at his incomplete intentions but also registers some limits of his dialectics.

\section{Alternative Dialectics of Nature}

Depending on how dialectics, opposition and contradiction are used, one can derive different meanings from a dialectics of nature that do not necessarily coincide with how it was conceptualized by Engels. Following the aforementioned illustrations, one can think of three alternative accounts:

Aristotle: There are real opposites in nature. They are neither contradictory nor dialectical, for contradictions arise from logical errors or difference of opinions in academic disputes. Dialectics, as it was coined by the Ancient Greeks, applies to an interpretational act of disproving counter-arguments of the opponent. As far as his Physics, Book V is concerned, one can add that unity and interconnection of opposites are contradictions. This, however, does not correspond to the opposite claim in Book VI that there is no such thing as a real contradiction. On the terrain of what Hegel and Engels used to call subjective dialectics, Aristotle links dialectics to opposites and contradiction. That he asserts that there are real opposites and contradictions in nature does not indicate that they are also dialectical. If he had spoken of a dialectics of nature, this would have been limited to the interpretation of, and dispute over, nature, without any further claim of an objective dialectics in nature. 
Kant: In a similar vein, Kant claims that there are real opposites that are neither contradictory nor dialectical. In comparison to Aristotle, Kant is less ambiguous in that he rules out real contradictions, for they apply to logical oppositions only. But this does not make them necessarily dialectical. In other words, logical oppositions are subject to contradictions, but not all logical oppositions are dialectical. Kant could have spoken of a dialectics of nature, though not in the sense that there are real opposites in nature. A Kantian dialectics of nature would arise from metaphysical assertions of conditionalityunconditionality or absolute-relative, which the human mind projects into nature. The illusion that metaphysical opposites do actually exist in nature independent of the human mind is what Kant calls dialectical. If there is a dialectics of nature, it would apply to this metaphysical confusion of the concept of nature.

Hegel: There are real and logical oppositions and contradictions. Opposites are structural elements of contradictions. Opposites that are not unified remain opposites; those that are unified constitute a contradiction. For Hegel, the aspect of negativity or exclusion refers to dialectics, that of positive and negative or unity of opposites to speculation. This idea is first formulated in his Logic as a logical self-description of how scientific thinking proceeds. Since nature is a manifestation of this logic, it necessarily follows that there are oppositions and contradictions in nature. If Hegel had a dialectics of nature, it would have referred to a) dialectics in nature in the sense that negativity of pure opposites applies to particular natural phenomena that develop towards contradiction; or b) dialectics of nature in the sense that logic and nature are non-contradictory opposites before logic externalizes itself into nature. After that externalization, one can speak of speculation, not dialectics, of nature.

What Engels would have said of these alternatives is open to interpretation. With his new 1880 plan where dialectics is replaced by motion, he would have hardly bothered with a broad discussion of these alternatives. We know at least that the textual material from the pre-1880 stage, or more specifically the $1874-78$ period, provides a more coherent picture. He would probably agree with Aristotle and Kant that there are logical and real opposites. Nevertheless, he would side here with Hegel: opposites are of dynamic nature and develop towards contradiction. While contradictions are speculative for Hegel, they are dialectical for Engels. He also downplays Hegel's idealism 
in the sense that nature is not a manifestation of logic, but rather logic mirrors nature. With this claim, he would be on the same page with Hegel that logic and nature are dialectical opposites in Hegel's sense of the term. Since there are real opposites and contradictions in nature, Engels would have said that dialectics applies to nature. In this regard, he is in full accord with Hegel's dialectics in nature in spite of Hegel's different usage of the term. While existence of real contradictions would prove for Hegel that speculation applies to nature, Engels would assert for the same reason that it proves that dialectics, not speculation, applies to nature. Concerning Hegel's dialectics of nature, Engels would perhaps speak of an opposition between the definition of a concept (i.e., dialectics, opposition, contradiction) and the reality to which this concept applies. Although the two-sided relation between concept and reality might be viewed as a polar opposition or two extreme sides of the same relation, they do not necessarily indicate a contradiction. Given the provisional distinction between dialectics of and in nature above, or alternative connections between dialectics and nature/natural science, the one-sidedness of the past titles given to Engels' book is quite obvious, for they disregard not only Engels' changing intentions or incomplete contentions on dialectics, but also his potential responses to alternative conceptualizations of dialectics of nature. This is then complicated by Kedrov's distaste for a dialectical ontology of nature and epistemological preference for dialectics of natural science (not nature). All in all, the complexity of the application problem of dialectics as in dialectics of, in and and nature is doubled by the relation of dialectics of, in and and natural science. Neither Engels nor his commentators, let alone Marx, are conclusive here. I believe this ambiguity is a good point of departure for further debate.

\section{Conclusion: Revisiting the Old Debate}

In this article, I first peeled off the interpretational and editorial layers of the Engels debate. Then I broke down Engels' arguments concerning his dialectics as it is related to, and distinguished from, past dialectical philosophies. Unlike a great majority of the former accounts in the Engels debate, my guiding thread remains Engels' intentions, incomplete or otherwise. This sort of perspective does not promise to solve problems of Engels' dialectics, but it provides us with 
a better set of questions. In other words, it makes the problematic relation between the author's intentions and his texts, the uneasy communication between his ideas and his readers' reactions as well as the editorial impacts on the creation of an author's image, more visible. Having said this, I would like to revisit the old debate one more time.

One of Engels' central concerns is certainly the application of dialectics to nature. However, he is rather at pains to prove that dialectics applies to reality in general. In this sense, he does not "follow" Hegel per se since he does not adopt a fixed categorial system (Lukács) and project it into nature (Hook, Lewis). He is primarily interested in natural scientific verification of Hegel's dialectical hypotheses.

This vision does not seem to have changed much throughout his entire project. Despite the terminological instability in different stages of his work, a shift from a Hegelian to a natural scientific Engels (Stepanov) is hardly the case. The textual material allows us to conclude that different aspects of dialectics, including a philosophical theory of totality, a method of thinking and a certain structure formed in reality were examined within the framework of the philosophy of nature, logic and natural sciences (Deborin). But this barely suggests that the project is more about a dialectics of the natural sciences than a dialectics of nature (Kedrov).

It is open to debate whether there can be a limited list of dialectical laws (Sartre). What we know is that Engels did not assume them from the very beginning but rather induced his laws post-factum from an intensive study of contemporary natural sciences. In 1880, he curiously dropped this idea, and shifted his focus to one key word: motion.

It is questionable whether Engels was keen to invent a theory of everything, even if he asserted the universality of dialectics (Schmidt, Lichtheim, Carver). It was clear to him that there is motion and it is everywhere, a concept which applies to nature, society and thought. Accordingly, the question concerning the validity of dialectics was closely connected to whether motion itself is something contradictory and dialectical (Vigier). I am not aware of any passage where Marx discusses this issue. However, Marx and Engels agree with Hegel that the dialectical relation of quality and quantity apply both to nature and society (Hoffman, Stanley, Zimmermann). Calling elliptical motion of planets a contradiction is also an idea they share (Weston, Kangal).

Naturally, editorial approaches have always been influenced by, and had a further impact on, such debates. Different choices of titles and rearrangements of the manuscripts reflect all of the 
political-philosophical concerns. To this extent, various decisions regarding the presentation of Engels' text are equally justified. Nonetheless, Engels' changing intentions throughout the work, the instability of his terminology and the incomplete character of his project allow an alternative title, such as "Philosophical-Natural Scientific Manuscripts." Its similarity to the title given to Marx' 1844 Manuscripts is obvious. But no one seems to have considered this option.

Regardless of what Engels could or should have said more than he already did, I think we must take the limitations of his achievements more seriously. If some scholars tend to view incompleteness as a sign of weakness, they are oblivious to the fact that incompleteness has an enabling rather than disabling effect on scientific progress. We know at least that this is how Engels thought scientific progress works. There is no reason why Engels' own work should be exempted from it.

Center for Studies of Marxist Social Theory

Department of Philosophy

Nanjing University

Xianlin Campus, Qixia District, 38

Jiangsu

Nanjing, 210046

China

\section{REFERENCES}

Althusser, Louis. 2005. For Marx. London: Verso.

Altvater, Elmar. 2015. Engels Neu Entdecken: Das Hellblaue Bändchen zur Einführung in die "Dialektik der Natur" und die Kritik von Akkumulation und Wachstum. Hamburg, Germany: VSA.

Aristotle. 1988. Physik. Vorlesung über Natur. Zweiter Halbband: Bücher V(E) - VII( $\Theta)$. Griechisch-Deutsch. Hamburg, Germany: Felix Meiner.

- 1991. Metaphysik. Zweiter Halbband: Bücher VII (Z) - XIV(N). Griechisch-Deutsch. Hamburg, Germany: Felix Meiner.

Arndt, Andreas. 2008. "Widerstreit und Widerspruch: Gegensatzbeziehungen in Frühromantischen Diskursen.” Internationales Jahrbuch des Deutschen Idealismus, $6,102-122$.

Attenborough, Mary. 1978. "The Dialectics of Nature." Marxism Today (January), 31-32.

Avineri, Shlomo. 1975. The Social and Political Thought of Karl Marx. London: Cambridge University Press.

Carchedi, Guglielmo. 2011. Behind the Crisis: Marx's Dialectics of Value and Knowledge. Leiden, The Netherlands: Brill. 
2012. "Mathematics and Dialectics in Marx: A Reply." Science E्F Society, 76: 4 (October), 546-549.

Carver, Terrell. 1980. "Marx, Engels and Dialectics." Political Studies, 28:3, 353-363.

—. 1983. Marx E Engels: The Intellectual Relationship. Sussex, England: Wheatshaf Books.

Cohen, Hyman R. 1980. "Countering the Revisionism of Marxist-Leninist Philosophy." Pp. 105-135 in Alan R. Burger, ed., Marxism, Science, and the Movement of History. Amsterdam: Grüner Publishing.

Colletti, Lucio. 1973. Marxism and Hegel. London: New Left Books.

Dai, Shan. 1978. "Yichang guanyu ziranbianzhengfa de zhenglun." Zhexueyicong (January), 52-58.

Deborin, Abram. 1924. "G. Lukach i ego kritika marksizma.” Pod Znamenem Marksizma, Nos. 6-7, 49-69.

- 1925. "Engels i dialekticheskoe ponimanie prirody." Pod Znamenem Marksizma, Nos. 10-11, 5-46.

- 1925b. "Materialistische Dialektik und Naturwissenschaft." Unter dem Banner des Marxismus, 3, 429-458.

Dühring, Eugen. 1865. Natürliche Dialektik: Neue Logische Grundlegungen der Wissenschaft und Philosophie. Berlin: Mittler.

—. 1873. Kritische Geschichte der Philosophie von ihren Anfängen bis zur Gegenwart. Berlin: Heimann.

— 1875. Cursus der Philosophie als Streng-wissenschaftlicher Weltanschauung und Lebensgestaltung. Leipzig, Germany: Heimann.

Einstein, Albert. 2015. "Opinion on Engels' 'Dialectics of Nature'.” Pp. 414 in The Collected Papers of Albert Einstein, Vol. 14. Princeton, New Jersey: Princeton University Press.

Engels, Friedrich. 1966. "Engels an Marx, 24 Mai 1876." In Karl Marx und Friedrich Engels, Werke, Vol. 34. Berlin: Dietz.

- 1974. "Engels an Marx, 7 Januar 1868." In Karl Marx und Friedrich Engels, Werke, Vol. 32. Berlin: Dietz.

— 1985. Dialektik der Natur (18731882). In Karl Marx und Friedrich Engels, Gesamtausgabe (MEGA), Vol. I/26.1. Berlin: Dietz.

- 1987a. Dialectics of Nature. Pp. 313-645 in Karl Marx and Frederick Engels, Collected Works, Vol. 25. Moscow: Progress Publishers.

- 1987b. Anti-Dühring. Pp. 1-309 in Karl Marx and Frederick Engels, Collected Works, Vol. 25. Moscow: Progress Publishers.

—. 1988. Herrn Eugen Dührings Umwälzung der Wissenschaft (Anti-Dühring). In Karl Marx and Friedrich Engels, Gesamtausgabe (MEGA), Vol. I/27.1. Berlin: Dietz.

Foster, John Bellamy. 2000. Marx's Ecology: Materialism and Nature. New York: Monthly Review Press.

Gemkow, Heinrich, ed. 1988. Friedrich Engels: Eine Biographie. Berlin: Dietz Verlag. Gray, Gordon. 1977. "The Dialectics of Nature.” Marxism Today (September), 287-288.

Greaves, Desmond. 1977. "The Dialectics of Nature." Marxism Today (August), 252256.

Gretskii, M. N. 1966. "Does Dialectics Exist in Nature?” Soviet Studies in Philosophy, $4: 4,56-62$. 
Griese, Anneliese, et al. 1985. "Dialektik der Natur, 1873-1882: Entstehung und Überlieferung." Pp. 569-607 in Karl Marx und Friedrich Engels, Gesamtausgabe (MEGA), Vol. I/26.2. Berlin: Dietz.

Griese, Anneliese, and Gerd Pawelzig. 1995. "Friedrich Engels' 'Dialektik der Natur': Eine Vergleichende Studie der Editionsgeschichte.” MEGA-Studien, 1995/1, 33-60.

Gunn, Richard. 1977. "Is Nature Dialectical?” Marxism Today (February), 45-52.

Hegel, G. W. F. 1986a. Vorlesungen über die Geschichte der Philosophie I. In Hegel, Werke, Vol. 18. Frankfurt, Germany: Suhrkamp.

—. 1986b. Enzyklopädie der Philosophischen Wissenschaften im Grundrisse 1830. In Hegel, Werke, Vol. 8. Frankfurt, Germany: Suhrkamp.

- 1986c. Nürnberger und Heidelberger Schriften 1808-1817. In Hegel, Werke, Vol. 4. Frankfurt, Germany: Suhrkamp.

—. 1986d. Wissenschaft der Logik II. In Hegel, Werke, Vol. 6. Frankfurt, Germany: Suhrkamp.

Hoffman, John. 1975. Marxism and the Theory of Praxis. London: Lawrence \& Wishart.

— 1977. "The Dialectics of Nature: 'The Natural-Historical Foundation of Our Outlook'." Marxism Today (January), 11-18.

Holz, Hans Heinz. 2005. Weltentwurf und Reflexion: Versuch einer Grundlegung der Dialektik. Stuttgart, Germany: Metzler.

Hook, Sidney. 1962. From Hegel to Marx: Studies in the Intellectual Development of Karl Marx. Ann Arbor, Michigan: University of Michigan Press.

$\mathrm{Hu}$, Chunfeng, ed. 2006. Ziranbianzhengfadaolun. Shanghai, China: Shanghai Renmin Chubanshi.

$\mathrm{Hu}$, Daping. 2011. Huidao Engesi. Wenbenlilun he jieduzhengzhixue. Nanjing, China: Jiangsu Renmin Chubanshi.

Jordan, Z. A. 1967. The Evolution of Dialectical Materialism: A Philosophical and Sociological Analysis. New York: St. Martin's Press.

Kangal, Kaan. 2017. “Carchedi’s Dialectics: A Critique.” Science Ẽ Society, 81:3, 427-436.

Kant, Immanuel. 2016a. "Versuch, über den Begriff der Negativen Grössen in die Weltweisheit Einzuführen.” Pp. 779-819 in Kant, Werke, Vol. I. Darmstadt, Germany: WBG.

— 2016b. Kritik der reinen Vernunft. In Kant, Werke, Vol. II. Darmstadt, Germany: WBG.

Kedrov, B. M. 1971. "Engels' Great Book." Soviet Studies in Philosophy, 10:1, 3-26. 1979. Friedrich Engels über die Dialektik der Naturwissenschaft. Berlin: Dietz.

Kołakowski, Leszek. 1978. Main Currents of Marxism: Its Rise, Growth, and Dissolution. Volume I: The Founders. Oxford, England: Clarendon Press.

Korch, Helmut. 1978. "Engels' Auffassung von der Dialektik der Natur und ihre Zeitgenössischen Gegner.” Pp. 270-292 in R. K. Kirchhoff and T. I. Oiserman, eds., 100 Jahre "Anti-Dühring”: Marxismus, Weltanschauung, Wissenschaft. Berlin: Akademie-Verlag.

Lenin, V. I. 1974. "Karl Marx. A Brief Biographical Sketch with an Exposition of Marxism.” Pp. 43-91 in Lenin, Collected Works, Vol. 21. Moscow: Progress Publishers.

Levine, Norman. 1975. The Tragic Deception: Marx Contra Engels. Oxford, England: Clio Books. 
. 2006. Divergent Paths: Hegel in Marxism and Engelsism. Volume 1: The Hegelian Foundations of Marx's Method. Lanham, Maryland: Lexington.

Levins, Richard, and Richard Lewontin. 1985. The Dialectical Biologist. Cambridge, Massachusetts: Harvard University Press.

Lewis, John. 1972. The Marxism of Marx. London: Lawrence \& Wishart.

Lichtheim, George. 1964. Marxism: An Historical and Critical Study. London: Routledge and Kegal Paul.

- 1972. Europe in the Twentieth Century. New York: Praeger Publishers.

Liedman, Sven-Eric. 1986. Das Spiel der Gegensätze: Friedrich Engels'Philosophie und die Wissenschaften des 19. Jahrhunderts. Frankfurt, Germany: Campus.

Lukács, Georg. 1971. History and Class Consciousness: Studies in Marxist Dialectics. Cambridge, Massachusetts: MIT Press.

—. 1977. Geschichte und Klassenbewußtsein. In Georg Lukács, Werke, Vol. 2. Neuwied, Germany: Luchterhand.

—. 1999. "Chvotismus und Dialektik (1925/26)." Pp. 119-159 in Lukács 1998/99: Jahrbuch der Internationalen Georg-Lukács-Gesellschaft. Paderborn, Germany:Janus-Druck.

- 2000. A Defense of History and Class Consciousness: Tailism and the Dialectic. New York: Verso.

Marx, Karl. 1974a. "Marx an Engels, 8 Januar 1868.” In Karl Marx und Friedrich Engels, Werke, Vol. 32. Berlin: Dietz.

- 1974b. "Marx an Engels, 11 Januar 1868." In Karl Marx und Friedrich Engels, Werke, Vol. 32. Berlin: Dietz.

—. 1974c. "Marx an Ludwig Kugelmann, 6 März 1868." In Karl Marx und Friedrich Engels, Werke, Vol. 32. Berlin: Dietz.

Merleau-Ponty, Maurice. 1947. "Marxism and Philosophy.” Politics, 4, 173-176.

Moran, Philip. 1980. "In Defense of the Dialectics of Engels' Dialectics of Nature." Pp. 57-76 in Alan R. Burger, ed., Marxism, Science, and the Movement of History. Amsterdam: Grüner Publishing.

Novack, George. 1996. Polemics in Marxist Philosophy. New York: Pathfinder.

Oiserman, T. I. 1978. "Friedrich Engels und die Neuen Kritiker des Dialektischen Materialismus.” Pp. 35-53 in R. K. Kirchhoff and T. I. Oiserman, eds., 100 Jahre "Anti-Dühring": Marxismus, Weltanschauung, Wissenschaft. Berlin: Akademie-Verlag.

Paolucci, Paul. 2007. Marx's Scientific Dialectics: A Methodological Treatise for a New Century. Leiden, The Netherlands: Brill.

Plato. 1972. Parmenides. Griechisch-Deutsch. Hamburg, Germany: Felix Meiner.

Rayner, Steve. 1977. "Dialectics of Nature." Marxism Today (May), 153-155.

Remley, William L. 2012. "Sartre and Engels. The Critique of Dialectical Reason and the Confrontation on the Dialectics of Nature." Sartre Studies International, 18:2, 19-48.

Rigby, S. H. 2007. Engels and the Formation of Marxism. History, Dialectics and Revolution. Manchester, England: Manchester University Press.

Sartre, Jean-Paul. 1947. "Materialism and Revolution." Politics, 4, 161-172.

- 2004. Critique of Dialectical Reason. Volume 1: Theory of Practical Ensembles. London: Verso.

Sayers, Sean. 1980a. "Dualism, Materialism and Dialectics." Pp. 67-143 in Richard Norman and Sean Sayers, eds., Hegel, Marx and Dialectic: A Debate. Sussex, England: Harvester Press. 
1980b. "On the Marxist Dialectic." Pp. 1-24 in Richard Norman and Sean Sayers, eds., Hegel, Marx and Dialectic: A Debate. Sussex, England: Harvester Press. Schmidt, Alfred. 1965. "Zum Verhältnis von Geschichte und Natur im Dialektischen Materialismus.” Pp. 103-155 in Existentialismus und Marxismus: Eine Kontroverse Zwischen Sartre, Garaudy, Hyppolite, Vigier und Orcel. Frankfurt, Germany: Suhrkamp.

- 1993. Der Begriff der Natur in der Lehre von Marx. Hamburg, Germany: Europäische Verlagsanstalt.

Sève, Lucien. 1992. "Dialektik der Natur und Natur der Dialektik." Dialektik, 1, 35-56.

Sheehan, Helena. 1993. Marxism and the Philosophy of Science: A Critical History. Highland Park, New Jersey: Humanities Press.

Stanley, John L. 2002. Mainlining Marx. New Brunswick, New Jersey: Transaction Publishers.

Stanley, John L., and Ernest Zimmermann. 1984. "On the Alleged Differences Between Marx and Engels.” Political Studies, 32, 226-248.

Stepanov, I. 1925. "Engels i mechanisticheskoe ponimanie prirody." Pod Znamenem Marksizma, Nos. 8-9, 44-72.

Timpanaro, Sebastiano. 1974. On Materialism. London: New Left Books.

Torbe, Ifor. 1977. "The Dialectics of Nature." Marxism Today (October), 314-317.

Xiao, Xianjing, et al. 2016. Ziranbianzhengfa gailun. Beijing: Higher Education Press.

Weston, Thomas. 2012. "Marx on the Dialectics of Elliptical Motion." Historical Materialism, 20:4, 3-38.

Wolff, Michael. 1980. "Über das Verhältnis Zwischen Logischem und Dialektischem Widerspruch.” Hegel-Jahrbuch 1979, 340-348.

Wu, Guolin, ed. 2014. Ziranbianzhengfa. Beijing: Qinghuadaxue Chubanshi.

Zhou, Lindong. 2001. "Yuedu 'Ziranbianzhengfa'." Dangdai Waiguomakesizhuyi Lilun, 174-202. 